\title{
Staatssteun
}

\section{Terugvordering van staatssteun vindt zijn plek in de Nederlandse wetgeving}

\author{
Mr. J.C. van Haersolte*
}

Per 1 juli 2018 heeft het staatssteunrecht zijn plek gevonden in de Nederlandse regelgeving. Althans, de terugvordering van onrechtmatige staatssteun. Wat regelt de Wet terugvordering staatssteun?

Wet Terugvordering staatssteun (in werking getreden op 1 juli 2018), Stb. 2018, 99

\section{Inleiding}

Op 1 juli 2018 is de Wet terugvordering staatssteun in werking getreden. Daarmee doet het staatssteunrecht zijn intrede in de Nederlandse wetgeving. Het staatssteunrecht heeft zijn basis in het Verdrag tot Werking van de Europese Unie (VWEU) en is nader uitgewerkt in verordeningen, beschikkingen, besluiten, soft law (mededelingen, richtsnoeren enzovoort) en jurisprudentie van het Hof van Justitie en het Gerecht. Op nationaal niveau waren in ons land geen wettelijke regels hierover van kracht. Dat is in beginsel ook niet nodig omdat het staatssteunrecht rechtstreeks werkt en er ook geen Nederlandse toezichthouder belast is met deze regels. 'In beginsel' want in de loop der jaren waren wel fricties aan het licht gekomen tussen beide rechtsordes.

In deze bijdrage wordt eerst ingegaan op de achtergrond van de nieuwe wet, vervolgens wordt commentaar gegeven op de afzonderlijke bepalingen en de bijdrage wordt afgesloten met enkele opmerkingen over aspecten die hier nog niet aan de orde zijn geweest.

\section{Achtergrond van en aanleiding voor de nieuwe wet}

De terugvordering van staatsteun is een belangrijk middel bij de handhaving van de staatsteunregels. De Euro-

* Mr. J.C. (Johan) van Haersolte is counsel bij Coupry Advocaten en tevens redactielid van NtEr. pese Commissie (hierna: Commissie) heeft samen met de nationale rechter een belangrijke taak bij de handhaving. Zij handhaven de staatssteunregels onder toezicht van het Hof van Justitie (rechtstreekse beroepen, prejudiciële vragen). Ook de nationale overheden, zowel centrale als decentrale, spelen een rol. Zij hebben vanzelfsprekend de algemene plicht tot het naleven van de staatssteunregels. ${ }^{1}$ In Nederland wordt dat aangevuld door de bevoegdheid van artikel 2 van de Wet Naleving Europese regelgeving publieke entiteiten (Wet NErpe). Dat artikel bepaalt dat de 'Minister die het aangaat' een aanwijzing kan geven aan de betrokken publieke entiteit om de steunmaatregel te melden in Brussel. ${ }^{2}$ Ook moeten hier de Provinciewet en de Gemeentewet worden vermeld. De bevoegdheden van de Wet NErpe zijn aanvullend ten opzichte van die in de Provinciewet en de Gemeentewet. ${ }^{3}$ Laatstgenoemde wetten voorzien in de volgende instrumenten, in toenemende ingrijpendheid: de waarschuwingsbrief, de schorsing en de vernietiging. Zij kunnen worden gebruikt door de minister van BZK wanneer provincies en gemeenten in strijd handelen met de staatsteunregels. ${ }^{4}$ Naast de Wet NErpe, de Provinciewet en de Gemeentewet, geldt sinds 1 juli 2018 de Wet terugvordering staatssteun (hierna: Wts). Deze wet beperkt zich, zoals de naam aangeeft, tot de terugvordering van staatssteun. De terugvordering kan als ultimum remedium worden gekenschetst omdat eigenlijk alle inspanningen juist gericht moeten zijn op het voorkomen van verboden steunmaatregelen.

De Commissie speelt een centrale rol maar is niet de instantie die terugvordert. Het zijn de nationale autoriteiten die de steun hebben verleend, die diezelfde steun terug moeten vorderen van de ontvanger. Daarbij moesten zij tot nu toe gebruikmaken van verschillende publiekrechtelijke bevoegdheden voor zover die tot hun beschikking stonden. Dit heeft in de loop der jaren geleid tot een weerbarstige praktijk. Deze praktijk vormt

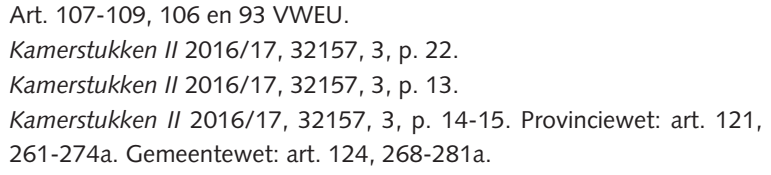


de reden voor de nieuwe wet. Voordat ik daarop inga, volgen hier wat opmerkingen over het toepasselijke Europeesrechtelijke kader.

Het Verdrag tot Werking van de Europese Unie (VWEU) als zodanig regelt niet de terugvordering. ${ }^{5} \mathrm{De}$ terugvordering zal altijd betrekking hebben op onrechtmatige staatssteun, steun waarover de Commissie in strijd met artikel 108 lid 3 VWEU niet in de gelegenheid is gesteld een oordeel uit te spreken of die (on)verenigbaar is verklaard met de interne markt. Dat de Commissie nadat de steun is teruggevorderd, tot de conclusie kan komen dat de steunmaatregel toch toegestaan is (niet is verboden), doet niet ter zake. ${ }^{6}$ Terugvordering is namelijk bedoeld als instrument om een juiste naleving van de meldingsverplichting bij de Commissie en opschortingsplicht af te dwingen. Zij is geregeld in Verordening (EU) 2015/1589 (hierna: de Procedureverordening) die uitvoering geeft aan artikel 108 VWEU. ${ }^{7}$

De Commissie kan twee soorten maatregelen nemen om de terugvordering in gang te zetten:

- het terugvorderingsbevel: ${ }^{8}$ dit bevel kan de Commissie nemen als zij meent dat er haast geboden is; de terugvordering is voorlopig van aard, namelijk totdat de Commissie zich heeft uitgelaten over de vraag of de steunmaatregel verboden is $;^{9}$

- het terugvorderingsbesluit: ${ }^{10}$ dit besluit kan de Commissie nemen wanneer zij een negatief besluit vaststelt met betrekking tot de steunmaatregel. ${ }^{11}$

Niet alleen de Commissie kan besluiten dat terugvordering moet plaatsvinden. Ook de nationale rechter kan daartoe opdracht geven in een rechtszaak waarin concurrenten, de steunverlener zelf of andere belanghebbenden zich beroepen op overtreding van de standstillbepaling van artikel 108 lid 3 VWEU. ${ }^{12}$ Dit gebeurt dan op instigatie van derden, met als argument de onrechtmatigheid van de steun en niet omdat de steun verboden zou zijn. In een dergelijk geval heeft de Commissie zich nog niet uitgelaten over de vraag of de steun verenigbaar is met de interne markt. De nationale rechter is behoudens uitzonderlijke omstandigheden zelfs verplicht een

5. Art. 107-109, 106 en 93 VWEU.

6. Verboden of onverenigbare staatssteun is steun die in strijd is met art. 107 VWEU; onrechtmatige staatssteun is steun die toegekend is in strijd met de procedurevoorschriften van art. 108 VWEU.

7. Art. $13 \mathrm{t} / \mathrm{m} 17$ Verordening (EU) 2015/1589. Te onderscheiden van de Uitvoeringsverordening (EG) $\mathrm{nr}$. 794/2004, waarin met betrekking tot terugvordering alleen is geregeld het toe te passen rentepercentage.

8. Art. 13 lid 2 Procedureverordening. De Commissie neemt het terugvorderingsbevel ter aanvulling op het opschortingsbevel dat geregeld is in art. 13 lid 1 Procedureverordening.

9. Een bevoegdheid die zelden wordt gebruikt door de Commissie, zie daarover A.J. Metselaar, Drie rechters en één norm, Deventer: Wolters Kluwer 2016, p. 60-61.

10. Art. 16 Procedureverordening.

11. Dat betekent dat in de praktijk sprake is van één document met twee 'boodschappen': (1) de steun is verboden en (2) de steun moet worden teruggevorderd.

12. P.C. Adriaanse, 'De rol van nationale rechters bij de terugvordering van onrechtmatige staatssteun', in: W. den Ouden (red.), Staatssteun en de Nederlandse rechter, Deventer: Kluwer 2005, p. 58, 73-85. terugvordering te gelasten. ${ }^{13}$ Dat een dergelijke opdracht tot terugvordering zou moeten plaatsvinden, betekent nog niet dat het in de praktijk ook gebeurt. Uit een inventarisatie die Adriaanse in 2005 uitvoerde, bleek dat de Nederlandse rechter deze vergaande stap niet had genomen. ${ }^{14}$ Ook in de jaren erna is dat, voor zover bekend, hoogst zelden gebeurd. ${ }^{15}$ Een reden hiervoor is mogelijk dat lang onduidelijk was in hoeverre in het civiele recht voor terugvordering was vereist dat de onderliggende overeenkomst als nietig moest worden beschouwd of worden verklaard. Het Hof van Justitie heeft dat in december 2011 opgehelderd in zijn arrest Residex. ${ }^{16}$ Terugvordering moet, nietigverklaring mag. ${ }^{17}$ Daarnaast kan ook een bestuursorgaan autonoom besluiten tot terugvordering zonder dat het daartoe opgedragen is door de Commissie. Het zal dan eerst moeten constateren dat er sprake is van staatssteun en dat in strijd met het procedurevoorschrift van artikel 108 lid 3 VWEU is gehandeld. Dat is een lastig te trekken conclusie. ${ }^{18}$ Niet alleen moet namelijk het bestuursorgaan erkennen dat het in het verleden iets verkeerds heeft gedaan maar ook moet het aantonen dat er inderdaad sprake is van staatssteun. Toch komt een dergelijke terugvordering een enkele keer voor, bijvoorbeeld in de zaak Zorg en Zekerheid waar het Zorginstituut had vastgesteld dat bij de vaststelling van de vereveningsbijdrage Zvw 2007 was gerekend met onjuiste verrekeningspercentages voor de hogekostencompensatie (HKC). Deze fout had geleid tot staatssteun ten gunste van de onderlinge waarborgmaatschappij Zorg en Zekerheid en diende te worden hersteld. De Afdeling Bestuursrechtspraak (hierna: ABRvS) was van mening dat het Zorginstituut bevoegd was over te gaan tot terugvordering op grond van onverschuldigde betaling. Dat er sprake was onrechtmatige staatssteun had het Zorginstituut afgeleid uit een positieve Commissiebeschikking. ${ }^{19}$ Later werd dat oordeel bevestigd door een advies van de Commissie aan de ABRvS. ${ }^{20}$ Een ander voorbeeld betreft de gemeente Zwolle die in 2003 een overeenkomst had gesloten met JCDecaux over door het reclamebedrijf exploiteren van straatmeubilair als reclameobjecten. Op basis van een onderzoek door het Nationaal Adviesbureau Buitenreclame (NABB) was de gemeente van mening dat de vergoedingen door JCDecaux niet marktconform waren. $\mathrm{Zij}$ vorderde in 2016 aanpassing van de overeenkomst van 2003 en tevens terugvordering van staatssteun door middel van nabetaling van marktcon-

13. HvJ 21 juli 2005, zaak C-71/04, Xunta de Galicia, ECLI:C:EU:2005:493, punt 49.

14. Adriaanse 2005, p. 78-85

15. Een zaak waar dat wel gebeurde betrof Rb. Noord-Nederland 16 december 2015, ECLI:NL:RBNNE:2015:5815 (Gem. Harlingen/ Spaansen Holding). De terugvordering (inclusief rente) was gebaseerd op, kort gezegd, partiële nietigheid en onverschuldigde betaling.

16. HvJ 8 december 2011, zaak C-275/10, Residex, ECLI:C:EU:2011:814, punt 48.

17. J. Montijn en N. Saanen, 'Het arrest Residex: terugvordering moet, nietigverklaring mag', NtEr 2012/4, p. 126-131.

18. Metselaar 2016, p. 301.

19. Beschikking van de Europese Commissie van 3 mei 2005, C(2005)1329 fin.

20. ABRvS 15 april 2015, ECLI:NL:RVS:2015:1152 (Zorg en Zekerheid). 
forme huurtarieven voor het straatmeubilair. ${ }^{21}$ In deze twee voorbeelden ging weliswaar het bestuursorgaan over tot terugvordering maar werd die stap voor de bestuursrechter respectievelijk de civiele rechter aangevochten door de begunstigde zodat het uiteindelijk de rechter is die die terugvordering definitief moet gelasten.

Het voorstel voor de Wet terugvordering staatssteun werd in juli 2017 ingediend bij de Tweede Kamer. ${ }^{22}$ De regering voerde verschillende redenen aan voor het wetsvoorstel. De voornaamste reden was de wens om een sluitende set nationaalrechtelijke grondslagen op te stellen voor gevallen waarin Nederland op last van de Commissie steun moet terugvorderen. Ook al gaat het volgens de regering om niet meer dan enkele besluiten per jaar, een eenduidige grondslag is, gezien de veelheid aan (meer of minder toereikende) bestaande nationaalrechtelijke rechtsgrondslagen, noodzakelijk voor de effectiviteit en onverwijldheid van de terugvordering. De wet beoogt in een lacune te voorzien. ${ }^{23}$

Een tweede reden was de toezegging die Nederland aan de Commissie had gedaan om een inbreukzaak die aanhangig was bij het Hof van Justitie van de rol gehaald te krijgen. Het ging om de $B P M-$ zaak $^{24}$ waarin was gebleken dat de ABRvS had geoordeeld dat de Algemene wet bestuursrecht (Awb) geen rechtsgrondslag bood voor de terugvordering van staatssteun ingevolge een Commissiebesluit. ${ }^{25}$ De ABRvS had er in dat geval een mouw aan gepast door gebruik te maken van een ongeschreven beginsel van bestuursrecht 'dat aan het betrokken bestuursorgaan in beginsel niet de bevoegdheid kan worden ontzegd een begunstigende beschikking met terugwerkende kracht in te trekken indien de omstandigheden daartoe aanleiding geven'. Zij koppelde dit beginsel aan de EU-beginselen van effectiviteit en gemeenschapstrouw $^{26}$ en oordeelde op grond hiervan dat terugvordering toegestaan was. Dat gold echter alleen voor het hoofdbedrag en niet de rente daarover. ${ }^{27}$ De Commissie reageerde met een infractieprocedure die afgewend kon worden door de toezegging van Nederland om dit gebrek bij wet te zullen herstellen. ${ }^{28}$

Voorts moet de Wts ook een oplossing bieden voor de praktische terugvorderingsproblemen die zich in de

21. Tussenuitspraak Rb. Overijssel 14 maart 2018, ECLI:NL:RBOVE: 2018:788 (Gem. Zwolle/ JCDecaux). De zaak was bij het afsluiten van dit artikel nog aanhangig, de rechtbank wilde zich laten voorlichten over de marktconformiteit van de overeenkomst door middel van een deskundigenrapportage.

22. Kamerstukken I/ 2016/17, 34753, 1 t/m 3.

23. Kamerstukken // 2016/17, 34753, 3, p. 1-2

24. BPM: Bijdrageregeling proefprojecten mestverwerking.

25. De zaak Fleuren Compost had betrekking op Besluit 2001/521/EG van 13 december 2000, PbEG 2000, L 189/13 en de Bijdrageregeling Proefprojecten Mestverwerking (BPM).

26. Op dat moment art. 10 EG-Verdrag, nu art. 4 lid 3 VEU. Inhoudelijk is er geen verschil.

27. ABRvS 11 januari 2006, ECLI:NL:RVS:2006:AU9416 (BPM).

28. Beschikking President HvJ 5 juni 2008, zaak C-401/07, ECLI:NL:C: 2008:326. Opvallend is dat de President van het Hof van Justitie spreekt van 'getroffen maatregelen' terwijl op dat moment eigenlijk hoogstens sprake kon zijn van toegezegde maatregelen die na het arrest strandden (het oude en later ingetrokken wetsvoorstel, Kamerstukken 31418). afgelopen jaren hebben voorgedaan in zowel het civiele, het bestuurs- als het fiscale recht. In telegramstijl: voordeel waarvan indirect begunstigden profiteerden, terugvordering van rente, verschillende en afwijkende verjaringstermijnen bij de instrumenten van onverschuldigde betaling en ongerechtvaardigde verrijking bij terugvordering in de context van privaatrechtelijke steun, de termijn bij de Nederlandse wettelijke rente ${ }^{29}$ vs. de termijn bij rente op grond van de Procedureverordening, de vraag of de onrechtmatigheid van de steun een 'nieuw feit' oplevert zoals vereist in het fiscale recht. Ook de knelpunten die aan het licht waren gekomen in de ABRvS-zaken Zorg en Zekerheid ${ }^{30}$ en Ridderstee ${ }^{31}$ moesten door de nieuwe wet geadresseerd worden. ${ }^{32}$

\section{Inhoud van de Wet terugvordering staatssteun}

\author{
Definities en onderscheid tussen bestuursrecht, \\ civiel recht en fiscaal recht
}

- $\quad$ Definities (art. 1 Wts)

De toepasselijkheid van de wet is afhankelijk van het bestaan van een Commissiebesluit dat tot terugvordering verplicht. ${ }^{33}$ 'Commissiebesluit' omvat volgens artikel 1 Wts drie typen maatregelen: (1) het terugvorderingsbevel als bedoeld in 13 lid 2 Procedureverordening, (2) het terugvorderingsbesluit als bedoeld in artikel 16 lid 1 Procedureverordening en (3) een besluit van de Commissie op basis van artikel 108 lid 3 VWEU dat verplicht tot terugvordering. De eerste twee besluiten zijn de reguliere maatregelen die de Commissie vaststelt op grond van de Procedureverordening. Wat het derde type maatregel is, is m.i. minder duidelijk. Volgens de Toelichting stelt de Commissie een dergelijk besluit vast wanneer niet de hoofdsom wordt teruggevorderd maar enkel en alleen de rente. Dat zou het geval kunnen zijn wanneer de steun verenigbaar wordt verklaard met de interne markt maar deze te vroeg is verleend, namelijk in strijd met de standstillverplichting van artikel 108 lid 3 VWEU. ${ }^{34}$ 
- Onderscheid tussen bestuursrecht, civiel recht en fiscaal recht (art. $2 \mathrm{Wts}$ )

De overheid kan staatssteun op verschillende wijzen verstrekken. Artikel $2 \mathrm{Wts}$, het 'kernartikel' volgens de regering, ${ }^{35}$ bepaalt dat de wet daarom steun bestrijkt zowel van bestuursrechtelijke, privaatrechtelijke als fiscaalrechtelijke aard. Voor alle drie de soorten van steun bevat de Wts een bevoegdheidsgrondslag voor terugvordering. Voor de eerste twee soorten biedt de wet een nieuwe instrument (de betalingsbeschikking) maar voor de terugvordering van fiscale steun sluit het aan bij bestaande instrumenten. ${ }^{36}$

\section{Algemeen regime: terugvordering van}

bestuursrechtelijke en privaatrechtelijke steun

\section{- De betalingsbeschikking (art. 3 Wts)}

Het nieuwe instrument is de 'beschikking tot betaling' (hierna: betalingsbeschikking) die vastgesteld wordt door het 'bestuursorgaan dat het aangaat'. ${ }^{37}$ Een dergelijke beschikking moet worden beschouwd als een beschikking tot betaling van een geldsom in de zin van artikel 4:86 Awb. De formulering 'bestuursorgaan dat het aangaat' omvat niet alleen het bestuursorgaan dat de steun zelf verstrekte maar ook het (hogere) bestuursorgaan dat verantwoordelijk is voor de verstrekking van bijvoorbeeld privaatrechtelijke staatssteun of dat overheidszeggenschap ${ }^{38}$ uitoefent op de steunverlenende entiteit. ${ }^{39}$ Artikel 3 lid $1 \mathrm{Wts}$ duidt het bedrag aan dat terugbetaald moet worden met de formulering 'de ingevolge een Commissiebesluit van een begunstigde terug te vorderen staatssteun'. Het precieze bedrag hangt samen met het doel van de terugvordering, de ongedaanmaking van het voordeel dat de begunstigde heeft genoten en het herstellen van de situatie van vóór de steunmaatregel. Vaak noemt het Commissiebesluit het bedrag in kwestie. Als dat niet is gebeurd, ${ }^{40}$ dan zal de lidstaat dat zelf moeten berekenen overeenkomstig hetgeen in het Commissiebesluit is bepaald, en in overleg met de Commissie. ${ }^{41}$ De betalingsbeschikking wordt gericht tot de begunstigde, dat is de onderneming die in vergelijking met zijn concurrenten het marktvoordeel heeft genoten ten gevolge van de steunmaatregel. ${ }^{42} \mathrm{De}$ begunstigde zal meestal expliciet zijn genoemd in het Commissiebesluit, ${ }^{43}$ maar dat hoeft niet altijd het geval te zijn. ${ }^{44}$

35. Kamerstukken I/ 2016/17, 34753, 3, p. 26, 32.

36. Lid 1 resp. 2 en 3 van art. 2 Wts.

37. Art. 3 lid $1 \mathrm{Wts}$.

38. Door middel van aandeelhouderschap, stemrechten, recht van benoeming van bestuurders of commissarissen enz.

39. Art. $1 \mathrm{Wts}$ bevat de definitie van 'bestuursorgaan dat het aangaat'. Zie ook Kamerstukken I/ 2016/17, 34753, nr. 3, p. 14-15, 27-28.

40. Bij fiscale zaken bijv. wordt de berekening van het steunbedrag relatief vaak overgelaten aan de lidstaat, Kamerstukken // 2016/17, 34753, 3, p. 2.

41. Kamerstukken // 2016/17, 34753, 3, p. 14, 27.

42. Het kan natuurlijk ook gaan om verschillende begunstigden.

43. Bijv. Starbucks in Commissiebesluit 2017/502 van 21 oktober 2015 , PbEU 2017, L 83/38.

44. Bijv. in Commissiebesluit 2016/288 van 27 maart 2015, PbEU 2015, L 59/87, Verenigd Koninkrijk - heffing over aggregaten. In dat besluit
Behalve het hoofdbedrag zal op grond van de nieuwe wet ook de rente moeten worden teruggevorderd. Dit is vastgelegd in artikel 3 lid $2 \mathrm{Wts} .{ }^{45}$ De begunstigde heeft immers ook een rentevoordeel genoten, namelijk vanaf het moment dat de steun beschikbaar kwam tot het moment van terugbetaling. Over die periode moet dan ook rente terugbetaald worden. Wanneer de Commissie niet het rentepercentage vermeldt in haar besluit zal het berekend moeten worden overeenkomstig de Uitvoeringsverordening. ${ }^{46}$ Het rentepercentage wordt periodiek vastgesteld door de Commissie. ${ }^{47}$ Het is in theorie ook mogelijk dat de terugvordering zich beperkt tot de rente. Dat kan gebeuren wanneer de steun verleend tijdens de standstillperiode achteraf door de Commissie verenigbaar met de interne markt wordt verklaard. ${ }^{48}$

De betalingsbeschikking moet eventueel worden aangevuld met bepalingen waarmee openstaande betalingsverplichtingen vervallen zodat automatische voortzetting van de steunverstrekking wordt voorkomen. ${ }^{49}$ Aansluitend hierop bepaalt artikel $6 \mathrm{Wts}$ dat het betrokken bestuursorgaan, bij bestuursrechtelijke steun, de rechtsverhouding met de begunstigde kan aanpassen. Hiermee kan naast de terugvordering zelf, de doorwerking daarvan in de bestaande rechtsverhouding worden geregeld. Het betrokken orgaan kan de beschikking die zij indertijd aan de begunstigde heeft gegeven, ambtshalve wijzigen of intrekken, of ambtshalve een nieuwe beschikking geven. Een dergelijke voorziening voor privaatrechtelijke terugvordering van steun achtte de regering niet nodig omdat partijen zelfstandig in staat zijn hun overeenkomst aan te passen of de mogelijkheid hebben de civiele rechter te adiëren. ${ }^{50}$

\section{- Terugvordering zonder Commissiebesluit (art. 7 Wts)} De regering stelt in de toelichting dat de $\mathrm{Wts}$ er niet toe strekt terugvordering te regelen in gevallen wanneer er geen sprake is van een Commissiebesluit. ${ }^{51}$ Wanneer een rechterlijke uitspraak strekt tot terugvordering vormt de ongedaanmaking van de steun volgens de regering een afdwingbaar gegeven, ontvalt de titel aan de staatssteunverstrekking en wordt de steunverstrekking als onverschuldigde betaling gekwalificeerd. ${ }^{52}$ Toch heeft arti-

werd het VK opgedragen de Commissie te informeren van welke begunstigden de steun teruggevorderd zou worden.

45. Hiermee wordt uitvoering gegeven aan art. 16 lid 2 Procedureverordening en aan de lacune blootgelegd in de hierboven besproken zaak Fleuren Compost.

46. Art. 9 t/m 11 Verordening (EG) nr. 794/2004; Kamerstukken II 2016/17, 34753, 3, p. 14,

47. Laatstelijk per 1 juli 2018. Zie http://ec.europa.eu/competition/state_ aid/legislation/reference_rates.html.

48. Kamerstukken I/ 2016/17, 34753, 3, p. 8, 13 en 27. In de MvT (p. 8 en 14) wordt hierbij gesteld dat het gaat om 'rente van op zichzelf rechtmatige, maar te vroeg verleende steun'. Dat is m.i. onjuist. De steun was en blijft onrechtmatig, want verstrekt tijdens de standstillperiode, maar wordt achteraf door de Commissie verenigbaar met de interne markt verklaard. Wat dan 'overblijft' is de verplichting om de genoten rente terug te betalen.

49. Art. 3 lid 3 Wts.

50. Kamerstukken // 2016/17, 34753, 3, p. 29-30.

51. Bijv. wanneer terugvordering zou voortvloeien uit een Nederlandse rechterlijke uitspraak.

52. Kamerstukken // 2016/17, 34753, 3, p. 12, 31. 
kel 7 lid $1 \mathrm{Wts}$ wel betrekking op terugvordering zonder Commissiebesluit maar het beperkt zich daarbij tot bestuursrechtelijke en fiscaalrechtelijke steun. ${ }^{53}$ Volgens de regering hebben namelijk partijen bij privaatrechtelijk verstrekte staatssteun genoeg mogelijkheden om hun privaatrechtelijke rechtsverhouding te wijzigen of de civiele rechter te vragen daarover te oordelen. ${ }^{54}$ Artikel $7 \mathrm{Wts}$ legt het bestuursorgaan dat het aangaat een verplichting op om de beschikking waarin de steunmaatregel is vastgelegd in strijd met artikel 108 lid 3 VWEU te wijzigen en de steun daarmee ongedaan te maken. ${ }^{55}$ Dat sprake is van staatssteun die teruggevorderd moet worden wegens strijd met artikel 108 lid 3 VWEU, kan volgens de regering blijken uit een Nederlandse of Europese rechterlijke uitspraak of uit een 'advies van de Commissie'. ${ }^{56}$ Artikel $7 \mathrm{~W}$ ts moet voor terugvorderingen die niet door de Commissie zijn opgedragen, worden beschouwd als een aanvulling op de grondslagen die in gebruik waren vóór de inwerkingtreding van de Wts. ${ }^{57}$ Hetgeen artikel 7 lid 2 en $4 \mathrm{Wts}$ regelt over rente geldt overigens wel voor alle drie de rechtsgebieden (bestuursrechtelijke, fiscaalrechtelijke én civielrechtelijke terugvordering). De verschuldigde rente moet worden berekend overeenkomstig de Procedureverordening. ${ }^{58}$ Opgemerkt moet worden dat artikel 7 m.i. alles bij elkaar lastig leesbaar is. Terwijl leden $1 \mathrm{t} / \mathrm{m} 3$ betrekking hebben op verschuldigdheid van de hoofdsom plus de rente ten gevolge van wijziging van de beschikking door het bestuursorgaan (bestuursrechtelijke en fiscaalrechtelijke context) heeft lid 4 alleen betrekking op de rente in civielrechtelijke context. ${ }^{59}$ Het gewrongen karakter van artikel 7 hangt wellicht samen met het uitgangspunt dat de regering hanteert. Volgens haar kan terugvordering van staatssteun zonder voorafgaand Commissiebesluit alleen aan de orde zijn in geval van een Nederlandse rechterlijke uitspraak waarin het staatssteunberoep wordt gehonoreerd en de titel van de

53. Kamerstukken // 2016/17, 34753, 3, p. 3, p. 12, 31.

54. Kamerstukken I/ 2016/17, 34753, 3, p. 25. Al Khatib is daar kritisch over, hij meent dat het argument van loyale samenwerking (art. 4 lid 3 VEU) dat de regering hanteert bij het stellen van regels met betrekking tot bestuursrechtelijke en fiscaalrechtelijke steun, evengoed geldt bij privaatrechtelijke steun. Daar komt bij, volgens Al Khatib, dat steun steeds vaker in een privaatrechtelijk jasje wordt gezet, zie Al Khatib 2018, p. 6.

55. Art. 7 lid 1 en 3 Wts. Hiermee wordt een expliciete grondslag gecreëerd en de lacune gevuld die gebleken was door ABRvS 15 april 2015, ECLI:NL:RVS:2015:1152 (Zorg en Zekerheid).

56. Kamerstukken I/ 2016/17, 34753, 3, p. 3, p. 31. De regering maakt niet duidelijk wat voor type 'advies' dat moet zijn om terugvordering te rechtvaardigen. Al Khatib (2018, p. 5) meent dat het om een advies van de Commissie aan de nationale rechter kan gaan. Al Khatib is van mening dat ook ingeval dat het bestuursorgaan zich realiseert dat het een fout heeft gemaakt, het bevoegd is tot terugvordering. Dat betekent m.i. dat eerst een beschikking moet worden gewijzigd (bij bestuursrechtelijke steun) of een overeenkomst moet worden gewijzigd (bij privaatrechtelijke steun) waarna pas de daadwerkelijk terugvordering kan plaatsvinden. Een illustratie hiervan is te vinden in het tussenvonnis van de Rechtbank Overijssel van 14 maart 2018, ECLI:NL:RBO VE:2018:788 (Gem. Zwolle/ JCDecaux).

57. Kamerstukken // 2016/17, 34753, 3, p. 2

58. Art. 7 lid 2 en 4 Wts.

59. Dus op basis van onverschuldigde betaling. Al Khatib is kritisch over het feit dat art. 7 lid 4 Wts zich beperkt tot overeenkomsten naar Nederlands recht, zie Al Khatib 2018, p. 6. steunverstrekking ontvalt. $^{60}$ Een staatssteunberoep wordt echter door de rechter zelden gehonoreerd, zo erkent de regering ook. De regering wekt daarmee de indruk te redeneren dat de aanwezigheid van het ene probleem (staatssteunberoep zelden succesvol) de noodzaak van een oplossing van een ander probleem (geen goede terugvordering mogelijk zonder voorafgaand Commissiebesluit) wegneemt. ${ }^{61}$

\section{- $\quad$ Verjaringstermijn bij terugvordering (art. $4 \mathrm{Wts}$ )}

De Procedureverordening bepaalt dat na tien jaar geen steun meer kan worden teruggevorderd. ${ }^{62}$ Die termijn gaat in op het moment dat de ontvanger van de steun begint te genieten, wanneer de steun daadwerkelijk aan hem wordt uitbetaald. ${ }^{63}$ In artikel $4 \mathrm{Wts}$ is vastgelegd dat de begunstigde zich met betrekking tot (informatie samenhangend met) de verstrekking van staatssteun niet kan beroepen op de volgens Nederlands recht geldende verjarings-, bewaar- of vernietigingstermijnen. Dit vloeit voort uit het Europese doeltreffendheidsbeginsel en uit Europese jurisprudentie. ${ }^{64}$ Volgens de regering heeft deze bepaling eigenlijk slechts een signalerende functie aangezien EU-rechtelijke termijnen altijd voorrang hebben op nationale termijnen. ${ }^{65}$ In het arrest Stichting ROM-projecten heeft het Hof van Justitie overigens een uitzondering toegelaten op de onverkorte toepassing van deze voorrangsregel. Deze Nederlandse kwestie betrof Europese steun in het kader van de structuurfondsen waarbij een beschikking van de Commissie gericht tot Nederland niet was gepubliceerd en waarvan de voorwaarden niet aan de eindbegunstigde waren medegedeeld. In een dergelijk geval en mits de goede trouw van de begunstigde kon worden aangetoond, kon de plicht tot terugbetaling van de subsidie wegens het niet voldoen aan de voorwaarden, vervallen. ${ }^{66}$ In het oorspronkelijke wetsvoorstel was de uitkomst van het arrest Stichting ROM-projecten gecodificeerd maar na opmerkingen van de Raad van State is artikel $4 \mathrm{Wts}$ zo komen te luiden dat deze casuïstische uitzondering niet in de wet was terug te vinden. ${ }^{67}$

- Verzuim, mettelijke rente, verjaring, dmangbevel, bestemming geinde som (art. 5 Wts)

In het verlengde van artikel $4 \mathrm{Wts}$ regelt artikel $5 \mathrm{Wts}$ het verzuim, de wettelijke rente en (opnieuw) verjaring. Op de betalingsbeschikking ${ }^{68}$ is titel 4.4 Awb (Bestuurs-

60. Kamerstukken I/ 2016/17, 34753, 3, p. 12.

61. Kamerstukken I/ 2016/17, 34753, 4, p. 4-5. De regering maakt onderscheid tussen de 'achterkantproblematiek' (de uitvoering van een rechterlijke uitspraak) en de 'voorkantproblematiek' (de fase voorafgaand aan een rechterlijke uitspraak) en verwijst daarbij naar het onderzoek van Metselaar 2016.

62. Art. 17 Procedureverordening.

63. HvJ 8 december 2011, zaak C-81/10, France Télécom/ Europese Commissie, ECLI:EU:C:2011:811, punten 80-90.

64. Kamerstukken // 2016/17, 34753, 3, p. 28

65. Kamerstukken I/ 2016/17, 34 53, 3, p. 25.

66. HvJ 21 juni 20017, zaak C-158/06, Stichting ROM-projecten, ECLI:EU:C:2007:370, prejudiciële verwijzing door het CBb.

67. Kamerstukken II 2016/17, 34753, 3, p. 28; Kamerstukken II 2016/17, 34753,4 , p. 8-9.

68. Art. 3 Wts. 
rechtelijke geldschulden) van toepassing. Artikel $5 \mathrm{Wts}$ bepaalt dat van die toepassing zijn uitgezonderd de bepalingen inzake verzuim en wettelijk rente (afdeling 4.4.2) en verjaring (afdeling 4.4.3). Die bepalingen zijn immers onverenigbaar met de eisen die het EU-recht stelt aan terugvordering van staatssteun. Als de begunstigde onderneming niet binnen de aanmaningstermijn betaalt, kan de geldsom worden ingevorderd bij dwangbevel. Een executiegeschil zoals verzet heeft niet van rechtswege schorsende werking maar op basis van artikel 438 lid 2 Rv kan die wel worden gevraagd aan de voorzieningenrechter. ${ }^{69}$ De geldsom die geind wordt bij terugvordering komt toe aan de entiteit die de steun heeft verstrekt of het hogere orgaan waartoe hij behoort. $^{70}$

\section{- Overgangsrecht (art. $8 \mathrm{Wts}$ )}

Het overgangsrecht is geregeld in artikel $8 \mathrm{Wts}$. Wanneer ter uitvoering van een Commissiebesluit vóór 1 juli 2018 al rechtshandelingen zijn verricht, mag het bestuursorgaan verder gaan op de ingeslagen weg en de terugvordering op die wijze afronden. Het is dus dan niet verplicht artikel lid $1 \mathrm{Wts}$ te volgen. ${ }^{71}$ Het staat overigens het bestuursorgaan vrij alsnog ervoor te kiezen de Wts te gebruiken om terugvordering te bewerkstelligen. Het wegvallen van de verplichting de Wts in een dergelijk geval te benutten, betekent immers niet een verplichting om de terugvordering voort te zetten op grond van het oude regime. ${ }^{72}$

\section{- Voorkomen is beter dan genezen (art. $9 \mathrm{Wts}$ )}

In februari 2013 deed de ABRvS uitspraak in de zaak Ridderstee. ${ }^{73}$ GS van Zuid-Holland had een subsidie verstrekt tot het bedrag van 200.000 euro opdat het bedrag niet de de-minimis drempel zou overstijgen, op basis van de van toepassing zijnde provinciale subsidieverordening die bepaalde dat in geval van staatssteun dat bedrag niet mocht worden overschreden. Ook bepaalde die verordening dat op de subsidieaanvrager de bewijslast rustte met betrekking tot relevante staatssteunaspecten. Omdat echter de ontvanger van de subsidie, Ridderstee Holiday, zulke gedetailleerde informatie (inclusief deskundigenadvies) had overgelegd om aan te tonen dat geen sprake was van staatssteun, vereiste het zorgvuldigheidsbeginsel, ${ }^{74}$ aldus de ABRvS, dat de verstrekker in dit geval informeel contact had gezocht met de Commissie om na te gaan of er überhaupt sprake was van staatssteun. In contact treden met de Commissie is echter een bevoegdheid, geen verplichting. ${ }^{75} \mathrm{Om}$ de

69. Kamerstukken I/ 2016/17, 34753, 3, p. 17, 29

70. Art. 5 lid $3 \mathrm{Wts}$ sluit aan op de definitie van 'bestuursorgaan dat het aangaat' van art. $1 \mathrm{Wts}$.

71. Dus bestuursrechtelijke en privaatrechtelijke terugvordering van staatssteun. Omdat er door de Wts materieel niets verandert aan fiscaalrechtelijke terugvordering, is regeling van het overgangsrecht daar niet nodig.

72. Kamerstukken // 2016/17, 34753, 3, p. 31-32

73. ABRvS 13 februari 2013, ECLI:NL:RVS:2013:BZ1245 (Ridderstee). Zie N. Saanen, 'De uitspraak Ridderstee Holiday: een drieluik van selectiviteit, handelsverkeer en zorgvuldigheid', NtEr 2013/7, p. 240-246.

74. Art. 3:2 Awb.

75. Zie verder hierover Saanen 2013, p. 244-245. mogelijk vergaande conclusie voortvloeiende uit deze uitspraak dat een overheid vaker dan eigenlijk nodig contact moet zoeken met de Commissie, te neutraliseren, is artikel $9 \mathrm{Wts}$ tot stand gekomen. Dat artikel voegt een lid toe an artikel 4:35 Awb (subsidieverlening) zodat subsidieverlening ook wordt geweigerd als het bestuursorgaan van oordeel is dat die verlening in strijd is met de staatssteunregels ex artikelen 107 en 108 VWEU. De toelichting op dit artikel geeft als voorbeeld dat 'zonder meer duidelijk is dat het gaat om onverenigbare staatssteun'. ${ }^{76}$ Daarmee wordt een algemene regel ingevoerd met betrekking tot de staatssteunaspecten van Nederlandse subsidies en op dit punt de afhankelijkheid ten opzichte van lokale subsidieregelgeving, zoals in het geval van Ridderstee Holiday, weggenomen. De verreikende 'vergewisplicht' die uit de Ridderstee-uitspraak kon worden afgeleid is daarmee van de baan: bij evidente strijd moet het bestuursorgaan eigenstandig subsidie weigeren. ${ }^{77}$

Specifiek regime: terugvordering van fiscale steun Het afwijkend regime van terugvordering van steun die voortvloeit uit de toepassing van een belastingwet (hierna: fiscale steun), is vastgelegd in artikel 2, leden 2 en 3 Wts. In het verleden was een knelpunt bij terugvordering van dergelijke steun het gegeven dat bij navordering van directe belastingen een 'nieuw feit' is vereist. Betwijfeld werd of de onrechtmatigheid van de steunverlening wegens schending van de Europese staatssteunregels als een nieuw feit kon worden gekwalificeerd. ${ }^{78} \mathrm{Om}$ fiscale steun te bestrijken brengt de Wts ten eerste wijzigingen aan in de Algemene wet inzake rijksbelastingen (Awr) en de Invorderingswet 1990 (IW 1990)..$^{79}$ Ten tweede wordt in de Provinciewet, ${ }^{80} \mathrm{de}$ Gemeentewet $^{81}$ en de Waterschapswet ${ }^{82}$ het fiscaal terugvorderingsregime van toepassing verklaard op staatssteun verstrekt in het kader van deze drie wetten. Het uitgangspunt is dat staatssteun toegekend in de vorm van een belasting ook als belasting teruggevorderd moet worden. ${ }^{83}$ Dat betekent dat bij fiscale terugvordering aangesloten wordt bij het bestaand instrumentarium en dat het in handen ligt van de belastinginspecteur (Awr), de ontvanger (IW 1990) of de ambtenaren daartoe gemachtigd krachtens de Provincie-, Gemeente- of Waterschapswet. De berekening van het exacte bedrag dat teruggevorderd moet worden door middel van een navorderingsaanslag of een naheffingsaanslag, laat de Commissie relatief vaak over aan de lidstaat. ${ }^{84}$

Ook aan rente is gedacht bij terugvordering van fiscale steun. Het nieuwe artikel 20b Awr bepaalt dat de rente

76. Kamerstukken I/ 2016/17, 34753, 3, p. 32.

77. Kamerstukken // 2016/17, 34753, 3, p. 10-11. Zie verder Metselaar 2016, p. 296-299, 300-301.

78. Kamerstukken // 2016/17, 34753, 3, p. 9

79. Invoeging van art. 20a-20b Awr resp. art. 63aa-63ab.

80. Art. 227 a lid 5 Provinciewet.

81. Art. 231 lid 5 en Bijlage I onder A onderdeel 6 'Wet terugvordering staatssteun', Gemeentewet.

82. Art. 123 lid 6 Waterschapswet.

83. Kamerstukken I/ 2016/17, 34753, 3, p. 2.

84. Kamerstukken I/ 2016/17, 34753, 3, p. 2, 15, 19, 26-27, 33-36. 
terug moet worden gevorderd overeenkomstig hetgeen bepaald is bij of krachtens de artikelen 16 lid 2, en 33 onderdeel e van de Procedureverordening. ${ }^{85}$ Ten slotte wordt opgemerkt dat terugvordering van fiscale staatssteun inclusief rente zonder voorafgaand Commissiebesluit gedekt wordt door artikel $7 \mathrm{Wts}$ (zie hiervoor). ${ }^{86}$

\section{Slotopmerkingen}

De huidige wet kent een lange voorgeschiedenis. Al in april 2008 werd een ander wetvoorstel ingediend zonder citeertitel maar met de volgende aanduiding 'Wijziging van het Burgerlijk Wetboek, de Algemene wet bestuursrecht en de Algemene wet inzake rijksbelastingen in verband met de tenuitvoerlegging van een beschikking van de Commissie van de Europese Gemeenschappen of een rechterlijke uitspraak inzake staatssteun, alsmede wijziging van het Burgerlijk Wetboek om de procedure voor het vaststellen van de wettelijke rente aan te passen (terugvordering staatssteun)'. ${ }^{87}$ Het voorstel had een grotere, althans andere ambitie dan de huidige wet. Behalve wijzigingen van de Algemene wet bestuursrecht en de Algemene wet inzake rijksbelastingen beoogde het namelijk ook het Burgerlijk Wetboek te wijzigen. ${ }^{88}$ Tevens was het de expliciete bedoeling dat de wet ook een bevoegdheid zou scheppen voor terugvordering bij het uitvoering geven aan een onherroepelijke uitspraak van een Europese of Nederlandse rechter. Het laatste dat werd vernomen over dit wetsvoorstel dateert van juni 2008 toen de Vaste Commissie voor Justitie vragen formuleerde in het kader van haar behandeling van dit voorstel. ${ }^{89} \mathrm{En}$ in november 2017 werd het wetsvoorstel ingetrokken naar aanleiding van de aanstaande nieuwe wet. ${ }^{90}$ Volgens de regering is het grote verschil met het oude wetsvoorstel dat de Wet terugvordering staatssteun kiest voor een zo veel mogelijke uniforme regeling ongeacht het karakter van de onderliggende rechtsverhouding. 91

De regering erkent dat een tweetal aspecten niet is vastgelegd in de Wet terugvordering staatssteun en dat zij daarmee wil wachten totdat de jurisprudentie is uitgekristalliseerd. Het ene punt betreft het niet op een allesomvattende wijze regelen van terugvorderen van staatssteun wanneer geen Commissiebesluit daaraan ten gronde ligt (art. $7 \mathrm{Wts}$, hierboven behandeld). ${ }^{92}$ Een ander punt is artikel $6 \mathrm{Wts}$ dat bepaalt dat het bestuursorgaan (naast de betalingsbeschikking) een beschikking kan nemen om de rechtsverhouding met de begunstigde nader te regelen. Dit betreft echter slechts een bevoegdheid en geen verplichting. De regering lichtte toe dat een verdergaande regeling in het kader van bestuursrechtelijke terugvordering niet mogelijk is omdat dat er van geval tot geval anders uit ziet. Het is daarom beter om eventuele jurisprudentie af te wachten. ${ }^{93}$

Tegen betalingsbeschikkingen op grond van deze wet ${ }^{94}$ kan in beroep worden gegaan, in eerste en enige aanleg, bij het College van Beroep voor het bedrijfsleven (CBb). Dat vloeit voort uit artikel $9 \mathrm{Wts}$ dat de Algemene wet bestuursrecht op dit punt wijzigt. ${ }^{95}$ Beroep heeft geen schorsende werking. Rechtsbescherming tegen besluiten en rechtshandelingen die betrekking hebben op de doorwerking op bestaande rechtsverhoudingen (bijv. in het kader van art. $6 \mathrm{Wts}$ ) zal daarentegen te vinden zijn in de rechtsbeschermingsbepalingen van toepassing op die rechtsverhoudingen. ${ }^{96}$ In geval van fiscale terugvordering geldt de gebruikelijke fiscale rechtsbescherming (bezwaar, (hoger) beroep en cassatie). ${ }^{97}$

Overigens kunnen begunstigden of de betrokken lidstaat beroep instellen bij het Gerecht tegen een terugvorderingsbesluit van de Commissie. Een dergelijk beroep heeft geen schorsende werking zodat de lidstaat ondertussen gedwongen blijft tot terugvordering over te gaan. Het zou echter kunnen gebeuren dat er reeds teruggevorderd is wanneer het Hof van Justitie of het Gerecht het terugvorderingsbesluit nietig verklaart. Lastig, maar de regering heeft besloten dat niet te regelen in deze wet. Zij meent dat er voldoende mogelijkheden bestaan voor (ambtshalve) herstel of herstel op basis van onverschuldigde betaling. Wel zal daartoe paragraaf 23 (Ambtshalve verminderen of teruggeven) ${ }^{98}$ van het Besluit Fiscaal Bestuursrecht worden aangepast. ${ }^{99}$

Ten slotte een kanttekening bij de getalsmatige noodzaak van de $\mathrm{Wts}$. De regering stelt in de Toelichting dat het voor Nederland gaat om niet meer dan enkele Commissiebesluiten per jaar. ${ }^{100}$ Een eenvoudige zoektocht in het State Aid Cases Register van de Commissie levert echter over de periode 1999-2018 slechts elf besluiten op, minder dan één per jaar. ${ }^{101}$ Dat lijkt mij een (veel) lager aantal dan "niet meer dan enkele per jaar". Op basis hiervan lijkt mij niet waarschijnlijk dat de betalingsbeschikking van de Wts vaak zal moeten worden gebruikt. De Wts zal zijn nut vooral hebben als stok achter de deur om overheden en marktdeelnemers in overeenstemming met de staatssteunregels te laten handelen, zonder dat het tot terugvordering hoeft te komen. het periodiek door de Commissie aangepaste rentepercentage, Kamerstukken I/ 2016/17, 34753, 3, p. 9 en 35.

86. Kamerstukken II 2016/17, 34753, 3, p. 31

87. Kamerstukken 31418.

88. Wijzigingen van de art. 6:119 en 6:120 en invoeging van een art. 6:212a in een nieuwe Afdeling 4 Terugvordering en ongedaanmaking van steun.

89. Kamerstukken // 2007/08, 31418, 5 .

90. Kamerstukken // 2007/08, 31418, 6 .

91. Kamerstukken II 2016/17, 34 53, 3, p. 3, 9.

92. Kamerstukken I/ 2016/17, 34753, 3, p. 12-13.
93. Kamerstukken I/ 2016/17, 34753, 3, p. 30.

94. Voor alle duidelijkheid, in het kader van bestuursrechtelijke en privaatrechtelijke staatssteun.

95. Invoeging van art. 3 Wts in art. 4 van bijlage 2 (Bevoegdheidsregeling bestuursrechtspraak) van de Awb.

96. Kamerstukken I/ 2016/17, 34753, 3, p. 2, 18-19, 20

97. Kamerstukken // 2016/17, 34753, 3, p. 19.

98. Uitwerking van art. 65 Awr.

99. Kamerstukken // 2016/17, 34753, 3, p. 11.

100. Kamerstukken // 2016/17, 34753, 3, p. 1.

101. http://ec.europa.eu/competition/elojade/isef/index.cfm. 